\title{
Comparison between Organic and Conventional Spelt and Wheatgrass juice
}

\author{
Boris M. Popović1, Dubravka M. Štajner ${ }^{1}$, Ružica Z. Ždero-Pavlović1, Marija I. Bodroža-Solarov², \\ Vladan M. Ugrenović3 ${ }^{3}$ Boško D. Marić2, Bojana Kalenjuk ${ }^{4 *}$, Lato L. Pezo ${ }^{5}$ \\ ${ }^{1}$ Department of Field and Vegetable Crops, Faculty of Agriculture, University of Novi Sad, \\ Trg Dositeja Obradovića 8, 21000 Novi Sad, Serbia \\ 2 Research Center for Technology of Plant Based Food Products, Institute for Food Technology, University of Novi Sad, \\ Bulevar cara Lazara 1, 21000 Novi Sad, Serbia \\ ${ }^{3}$ Agricultural Professional Service, PSS Institute "Tamiš", Novoseljanski put 33, Pančevo, Serbia \\ ${ }^{4}$ Department of Geography, Tourism and Hotel Management, Faculty of Sciences, University of Novi Sad, \\ Trg Dositeja Obradovica 3, 21000 Novi Sad, Serbia \\ ${ }^{5}$ Engineering Department, Institute of General and Physical Chemistry, University of Belgrade, \\ Studentski Trg 12 - 16, 11000 Belgrade, Serbia \\ *Corresponding author, e-mail: bojanakalenjuk@yahoo.com
}

Received: 27 February 2019, Accepted: 07 May 2019, Published online: 15 June 2019

\begin{abstract}
This work is aimed to compare antioxidant and scavenger properties of conventionally and organically produced speltgrass. Moreover, the antioxidant status of spelt was compared with wheatgrass. Three spelt varieties were analyzed:Nirvana, Ebners-Rotkorn variety and Eco-10. Antioxidant enzymes, superoxide-dismutase and guiacol-peroxidase, were determined as well as ferric reducing antioxidant power and DPPH-antiradical power. Total soluble proteins and total phenols were determined and also lipid peroxidation as a parameter of oxidative stress. The organically produced spelt was exposed to the higher levels of oxidative stress than conventionally produced spelt, and also DPPH antiradical power was induced by conventional production, which is also demonstrated using the relative antioxidant capacity index. The best antioxidant properties, better than wheat, showed organically produced spelt genotype Ebners-Rotkorn which is determined by the highest phenol content, superoxide-dismutase activity, DPPH antiradical power and ferric reduced antioxidant power and consequently with the lowest lipid peroxidation intensity.
\end{abstract}

Keywords

grass juice, Triticum aestivum ssp., spelt, Triticum aestivum, antioxidant activity, lipid peroxidase

\section{Introduction}

Spelt (Triticum aestivum ssp. spelt) is an ancient subspecies of modern bread wheat (Triticum aestivum). For many years, cultivation of spelt declined, due to spelt's lower yield and its long straw with a tendency to lodge. In recent years, interest in the use of spelt increased, because it is considered as "healthier" and more "natural" grain than modern wheat. Spelt wheat is a suitable for growing without the use of pesticides, in harsh ecological conditions and in marginal areas of cultivation [1]. Moreover, spelt is more tolerant of poorly-drained and low-fertility soils than other commonly cultivated cereals [2].

Spelt possesses a valuable nutritional quality. Specificity of spelt in relation to wheat is in favor of spelt, which possesses more bioactive components in neo-saponified part of the liposoluble fraction [3]. It has higher protein content than wheat, some mineral contents, including selenium and zinc as well as high fiber content $[4,5]$. Wheat contains diverse bioactive compounds that may contribute to its antioxidant capacity. These bioactive components include carotenoids, tocopherols, tocotrienols, phenolic acids, phytic acid, phytosterols and flavonoids [6, 7]. Previous studies have shown that wheat varieties vary in antioxidant properties as well as in composition in secondary biomolecules including antioxidants [8].

Wheatgrass (aboveground parts of the wheat) was traditionally used in ancient Egypt and perhaps even early Mesopotamian civilizations. Wheatgrass and spelt grass are powerful, concentrated liquid nutrients which have 
been used as home-made remedy or commercially distributed as frozen juice or powdered and freeze dried [9, 10]. Like most plants, it contains chlorophyll, amino acids, minerals, vitamins, and enzymes. It was reported the significant presence of polyphenols and other flavonoids responsible for antioxidant activity as well as a diverse class of organic compounds in the aqueous extract, ranging from saturated and unsaturated fatty acids, alcohols and terpenes [11]. It has also been believed that wheatgrass could strengthen the immune system and increase the life span of cancer patients by regressing the spread of cancer cells [12].

Organic agriculture implies no use of synthetic fertilizers, genetically modified materials, sewage sludge or pesticides. Although the production and need for organic production are recently increasing in the world, it is necessary to find determination method for organic food quality determination with focus on laboratory methods [13]. Many studies found that organic methods produced lower yields and therefore required more land for a given production level [14]. A recent life cycle assessment (LCA) study showed that organic farming was either superior or similar to the conventional integrated production, but with exceptions for some products [15]. It was found that spelt endures well under suboptimal growing conditions [16], and to better utilize nutrients when grown in a low-input system [17], and show more resistance to a number of pathogens [18], than common wheat, thus spelt is recommended for organic agriculture.

Principal Component Analysis (PCA) was applied as a well known pattern recognition technique to the experimental data (used as descriptors) to characterize and differentiate among the observed samples.

Based on results obtained employing all antioxodant capacity (AOC) assays, relative antioxidant capacity index (RACI) has been calculated. Antioxidant efficiency of phenolics present in analyzed samples has been estimated based on phenolic antioxidant coefficients (PAC), determined as a ratio between particular AOC and total phenolic content (TPC), and compared to obtain a more comprehensive insight into the activity of analyzed samples.

In this way, the present study aimed to compare the antioxidant activity of organically and conventionally produced speltgrass and wheat grass. In order to evaluate antioxidant status of spelt and wheat antioxidant enzymes (superoxide-dismutase and guiacol-peroxidase), soluble proteins, total phenol content, 2,2'-Diphenyl-1Picrylhydrazyl (DPPH) antiradical power, ferric reducing antioxidant power and lipid peroxidation were determined.

\section{Materials and Methods}

\subsection{Chemicals and reagents}

2,2'-Diphenyl-1-Picrylhydrazyl(DPPH), 2,4,6-TripyridylTriazine (TPTZ), Nitro Blue Tetrazolium (NBT), Guaiacol (2-methoxyphenol), Folin and Ciocalteu-phenol reagent, 2-Thiobarbituric acid, ferric chloride and monobasic potassium phosphate were obtained from SigmaAldrich (Beograd, Serbia). All reagents and chemicals were of analytical grade.

\subsection{Material}

The field experiment was carried out on three spelt variety (Triticum aestivum subs. spelt) and one wheat (Triticum aestivum). The spelt variety used in the experiment was Eco10 and Nirvana, which were supplied from a Serbian market and one variety (Ebners-Rotkorn) which was supplied from an Austrian market. The wheat variety used in the experiment was Europa 90.

\subsection{Field experiment}

The experiments were conducted at locality Institut "Tamiš" Pančevo (N 44 56', E $20^{\circ} 43^{\prime}$ ) on the chernozem type of soil in the 2010-2011 vegetation season.The trial was set up in a randomized complete block design with four replicates. Each plot consisted of 10 rows, $10 \mathrm{~cm}$ apart and $5 \mathrm{~m}$ long (the harvested area was $5 \mathrm{~m}^{2}$ ). Seedling density was considered as $500 \mathrm{seeds} / \mathrm{m}^{2}$. Growth stages of wheat were 30 (BBSH, 2001) [19].

\subsection{Extraction procedures}

Plant material was previously frozen at $-70{ }^{\circ} \mathrm{C}$ in SNIJDERS deep freezer (VF360-86). For the freeze-drying process, frozen leaves were liophylizedin a Martin Crist Alpha 1-2 LDplus (Osterode, Germany) lyophilizator. The main drying process was performed at $\mathrm{p}=0.12 \mathrm{mbar}$ and temperatures from $-40{ }^{\circ} \mathrm{C}$ to $20^{\circ} \mathrm{C}$ for $48 \mathrm{~h}$. The final drying lasted $5 \mathrm{~h}$ at $\mathrm{p}=0.005$ mbar and temperatures from $20^{\circ} \mathrm{C}$ to $30^{\circ} \mathrm{C}$. Plant material (1 g dry leaves) was extracted with $25 \mathrm{ml} 80 \%$ aqueous ethanol $(0.1 \mathrm{M} \mathrm{HCl})$ under $30 \mathrm{~min}$ sonication in an ultrasonic bath (Elmasonic S 100-H; Elma Schmidbauer $\mathrm{GmbH}$ ) at ambient temperature. The extract was rapidly vacuum-filtered through a sintered glass funnel and kept refrigerated. This extract was used for determination of total phenol content, ferric reducing antioxidant power (FRAP) and DPPH antiradical power.

For the determination of lipid peroxidation (LP) and antioxidant enzymes, $2 \mathrm{~g}$ of plant material (fresh leaves) was extracted with $10 \mathrm{ml} 0.1 \mathrm{M} \mathrm{K}_{2} \mathrm{HPO}_{4}(\mathrm{pH}$ 7.0) under 
30 min sonication in an ultrasonic bath at ambient temperature. After10 minutes of centrifugation at $4{ }^{\circ} \mathrm{C}$ and $10,000 \mathrm{xg}$, aliquots of the supernatant were used for enzyme activity determinations. The used centrifuge was BOECO Germany (U-320-R).

\subsection{Antioxidant enzymes and soluble proteins}

The superoxide dismutase (SOD) activity was assayed according to Giannopolitis and Ries [20], by measuring the ability of the enzyme extract to inhibit the photochemical reduction of nitro-blue tetrazolium (NBT). Glass test tubes containing the mixture were immersed in a bath at $25^{\circ} \mathrm{C}$ and illuminated by a fluorescent lamp (Philips MLL $5000 \mathrm{~W}$ ). Identical tubes, which were not illuminated, served as blanks. After illumination for $15 \mathrm{~min}$, the absorbance was measured at $560 \mathrm{~nm}$, using Thermoscientific UV-Visible spectrophotometer (Evolution 220). One unit of SOD was defined as the enzyme activity which inhibited the photoreduction of nitro-blue tetrazolium to the blue formazan by $50 \%$, and SOD activity of the extracts was expressed as SOD units per mg of protein. Reaction medium was prepared by mixing $2.6 \mathrm{~mL} 50 \mathrm{mM}$ phosphate buffer ( $\mathrm{pH} 7.8$ ), $100 \mu \mathrm{L} 13 \mathrm{mM}$ methionine, $100 \mu \mathrm{L} 75 \mu \mathrm{M}$ NBT, $100 \mu \mathrm{L}$ $0.1 \mathrm{mM}$ EDTA and $50 \mu \mathrm{L} 2 \mu \mathrm{M}$ riboflavin.

The guaiacol peroxidase (GPx) activity was measured following the method of Kato and Shimizu [21]. The activity was calculated using the extinction coefficient of $26.6 \mathrm{mM}^{-1} \mathrm{~cm}^{-1}$ at $470 \mathrm{~nm}$ for oxidized tetraguiacol polymer. One unit of GPx activity was defined as the calculated consumption of $1 \mu \mathrm{mol}$ of $\mathrm{H}_{2} \mathrm{O}_{2} \mathrm{~min}^{-1} \mathrm{mg}$ protein ${ }^{-1}$.

Soluble proteins were determined by the Bradford method (1976) [22]. Reaction medium contained $1 \mathrm{~mL}$ 0.07 MCommaise brilliant blue in $3 \% \mathrm{HClO}_{4}, 1 \mathrm{~mL}$ destilled water and $25 \mu \mathrm{L}$ of sample or standard (bovine serum albumin). After 5 min of incubation, absorbance of samples and standard was recorded at $\lambda=595 \mathrm{~nm}$. Protein concentration was read from calibration curve and finally expressed as mg protein/g dry matter.

\subsection{Total phenols content (TPC)}

The total phenolic content was determined by a modification of the Foline-Ciocalteu method and the results expressed as $\mathrm{mg}$ Gallic acid/100 g dry weight [23, 24]. In $4.2 \mathrm{~mL}$ of distilled water, $50 \mu \mathrm{L}$ of the corresponding extract was added and $250 \mu \mathrm{L}$ of Folin\&Ciocalteu-phenol reagent (previously diluted 1:10 with distilled water). The mixture was neutralized with $20 \%$ sodium-carbonate solution after 5 minutes, and the content transferred into a $1.5 \mathrm{~mL}$ cuvette (1 cm path); absorbance was determined after $60 \mathrm{~min}$ at $720 \mathrm{~nm}$.

\subsection{DPPH antiradical power (DPPH)}

The scavenging activity against DPPH radical was evaluated according to the method of Brand-Williams, Cuvelier, and Berset (1995) [25] with minor modifications. The assay mixture contained $2.9 \mathrm{~mL}$ DPPH solution $(90 \mu \mathrm{mol} / \mathrm{L})$ and $0.1 \mathrm{~mL}$ of the sample solution containing from 1 to $100 \mathrm{mg} / \mathrm{mL}$ dry extract; the final volume was $3 \mathrm{~mL}$. The mixture was shaken vigorously on a Vortex mixer, then incubated $60 \mathrm{~min}$ at $25{ }^{\circ} \mathrm{C}$ in a water bath in the dark, after which the absorbance of the remaining DPPH was determined at $517 \mathrm{~nm}$ against a blank. Blank was sample at the same concentration above described containing all reagents except DPPH. For each sample three replicates were carried out. Radical Scavenging Capacity (RSC) was calculated by the Eq. (1):

$$
\mathrm{RSC}=\left(\left(A_{0}-A_{1}\right) / A_{0}\right) \times 100
$$

where $A_{0}$ is the control and $A_{1}$ is the sample solution absorbance. The concentration (in the final reaction medium in each method) that causes a decrease in the initial absorbance (control) by $50 \%$ is defined as $\mathrm{IC}_{50}$. The $\mathrm{IC}_{50}$ values for all $\mathrm{RSC}$ determinations were determined by polynomial fitting of the inhibition values using software ORIGIN 9.1.

DPPH antiradical power defined as:

$\mathrm{DPPH}=\left(1 / \mathrm{IC}_{50}\right) \times 100$.

\subsection{Ferric reducing antioxidant power (FRAP)}

Total antioxidant capacity was estimated according to the FRAP assay [26]. The FRAP reagent was prepared by mixing acetate buffer (300 mM, pH 3.6), 2,4,6-tripyridyl-triazine reagent $(10 \mathrm{mM}$ in $40 \mathrm{mM} \mathrm{HCl})$ and $\mathrm{FeCl}_{3} \cdot 6 \mathrm{H}_{2} 0(20 \mathrm{mM})$ in the ratio of 3:1:1. A sample of $10 \mu \mathrm{l}$ was mixed with $3 \mathrm{ml}$ of working FRAP reagent and absorbance (593 nm) was measured 4 minutes after vortexing. The test was performed at $37^{\circ} \mathrm{C}$. The FRAP value was calculated using Eq. (3):

$$
\begin{aligned}
\text { FRAP value }= & \Delta A \text { sample }(0-4 \mathrm{~min}) \\
& / \Delta A \text { standard }(0-4 \mathrm{~min}) .
\end{aligned}
$$

The $100 \mu \mathrm{M} \mathrm{Fe}_{2}^{+}$solution was used as a standard; 1 FRAP unit $=100 \mu \mathrm{M} \mathrm{Fe}_{2}{ }^{+}$. Total antioxidant capacity was expressed in FRAP units. 


\subsection{Lipid peroxidation (LP)}

Lipid peroxidation was estimated based on thiobarbituric acid (TBA) reactivity. Samples were evaluated for malondialdehyde (MDA) production using a spectrophotometric assay for TBA. The extinction coefficient at 532 $\mathrm{nm}$ of $153,000 \mathrm{~mol}^{-1} \mathrm{~cm}^{-1}$ for the chromophore was used to calculate the MDA-like TBA produced. The color intensity of the MDA-TBA complex in the supernatant was measured by its absorbance at $532 \mathrm{~nm}$ [27].

\subsection{Statistical analysis}

All determinations were performed in quadruplicate. Statistical comparisons between samples were performed with Student's t-test for independent observations. Differences were considered significant at $p<0.05$. The antioxidant test results were investigated with multivariate analysis. The correlation matrix was calculated, giving the correlation coefficients between each pair of variables, i.e. the analytical parameters tested. Each term of the matrix is a number ranging from -1 to +1 : the + or - sign indicates a positive or negative interdependence between variables (direction), and the absolute value indicates the strength of the interdependence. Correlations between different parameters were considered significant at $p<0.05$ level. Principal component analysis (PCA) was used to discover the possible correlations among measured parameters, while Cluster analysis (CA) is used to classify objects into groups.

The data were processed statistically using the software package STATISTICA 10.0 (StatSoft Inc., Tulsa, OK, USA).

\section{Results and discussion}

The widely used spectrophotometric assays, such as FRAP and DPPH, were applied in parallel with GPx, SOD and LP to measure AOC of antioxidant and scavenging activities of organic and conventional spelt and wheatgrass, which TPC was determined using FC assay was shown in Table 1. A large variation in phenolic content was noticed.

\subsection{Soluble proteins and lipid peroxidation}

Soluble protein content ranged from 18.45 (Eco-10 spelt, conventional) to $25.00 \mathrm{mg} / \mathrm{g}$ (Nirvana spelt, conventional). Lipid peroxidation (MDA content) ranged from 14.03 (Nirvana spelt, conventional) to $18.18 \mathrm{nmol} \mathrm{MDA} / \mathrm{mg}$ protein (Eco-10 spelt, organic). Soluble protein content and LP was negatively correlated. Results are given in Table 1.

It was observed that conventionally produced Nirvana possessed $9.40 \%$ higher soluble protein content than organically produced one. Between organically and conventionally produced Eco-10 no significant difference was observed. In both investigated spelt genotypes (Eco-10 and Nirvana), lipid peroxidation was higher in organically produced spelt for $11.95 \%$ and $16.46 \%$, respectively.

Evidence suggests that organic cropping systems generally produce lower, more variable yields than systems employing synthetic fertilizers and chemical crop protection measures. According to Palmer et al. [28], the major limiting factor for yields in organic production systems is limiting nitrogen supply. Our results are in agreement with mentioned observations. Organic production of spelt did not provoke accumulation of soluble proteins, but contrary, the highest accumulation of soluble proteins was observed in conventionally produced spelt genotype Nirvana. Lipids are highly susceptible to oxidation and lipid peroxidation products, such as MDA quantity, are potential biomarkers for oxidative stress status in vivo [29]. Proteins are also the direct target for Reactive Oxygen Species (ROS) because of their high concentrations. Predictably, the lipid peroxidation intensity was significantly lower in conventionally produced spelt than in the organic spelt where protective measures did not apply.

Table 1 Experimental results of antioxidant and scavenging activities of organic and conventional spelt and wheatgrass

\begin{tabular}{|c|c|c|c|c|c|c|c|c|c|}
\hline & Sample & Treatment & SPC & GPx & SOD & LP & TPC & DPPH & FRAP \\
\hline 1 & Eco-10 & Organic & $20.00^{\mathrm{a}}$ & $5.64^{\mathrm{b}}$ & $10.33^{\mathrm{ab}}$ & $18.18^{c}$ & $698.10^{\mathrm{a}}$ & $2.75^{\mathrm{c}}$ & $27.20^{\mathrm{a}}$ \\
\hline 2 & Eco-10 & Conv. & $18.45^{\mathrm{a}}$ & $5.94^{\mathrm{b}}$ & $11.38^{\mathrm{bc}}$ & $16.24^{\mathrm{b}}$ & $720.20^{\mathrm{a}}$ & $1.70^{\mathrm{a}}$ & $25.25^{a}$ \\
\hline 3 & Nirvana & Organic & $22.65^{b}$ & $6.96^{\mathrm{c}}$ & $12.23^{\mathrm{c}}$ & $16.34^{\mathrm{b}}$ & $713.20^{\mathrm{a}}$ & $2.37^{\mathrm{b}}$ & $31.35^{\mathrm{b}}$ \\
\hline 4 & Nirvana & Conv. & $25.00^{c}$ & $3.80^{\mathrm{a}}$ & $9.44^{\mathrm{a}}$ & $14.03^{\mathrm{a}}$ & $750.40^{\mathrm{ab}}$ & $1.54^{\mathrm{a}}$ & $32.75^{b}$ \\
\hline 5 & Ebners-R & Organic & $20.25^{\mathrm{a}}$ & $5.88^{\mathrm{b}}$ & $19.38^{d}$ & $14.40^{\mathrm{a}}$ & $877.20^{c}$ & $1.52^{\mathrm{a}}$ & $39.35^{\circ}$ \\
\hline 6 & Europa 90 & Organic & $22.20^{\mathrm{b}}$ & $9.05^{\mathrm{d}}$ & $9.26^{\mathrm{a}}$ & $16.09^{\mathrm{b}}$ & $816.70^{\mathrm{bc}}$ & $2.36^{\mathrm{b}}$ & $32.55^{\mathrm{b}}$ \\
\hline
\end{tabular}

Values with the same letter are not statistically different at the $p<0.05$ level (post hoc Tukey's HSD test); SPC (mg/ml) - soluble protein content; GPx (U/mg protein)- guaiacol peroxidase activity; SOD (U/mg protein) - superoxide dismutase activity; LP MDA (nmol/mg protein) () - lipid peroxidation enzyme, TPC (catechin eq (mg/100g dw))- total phenolic content 


\subsection{Soluble proteins and lipid peroxidation}

The SOD activity ranged from 9.26 (wheat, organically produced) to $19.38 \mathrm{U} / \mathrm{mg}$ protein (Ebners-R spelt, organically produced). GPx activity ranged from 3.8 (Nirvana spelt, organic) to $9.05 \mathrm{U} / \mathrm{mg}$ protein (wheat, organically produced). No significant correlations between antioxidant enzymes and with LP and soluble proteins were found. Both antioxidant enzymes were significantly higher in organically produced spelt Nirvana, for $29.56 \%$ (SOD) and for $83.16 \%$ (GPx). Results are given in Table 1 .

SOD catalyzes the dismutation of superoxide radical in all living tissues, including plants, leading to hydrogen-peroxide production. Peroxidases are haem-containing enzymes that use hydrogen peroxide as the electron acceptor to catalyze a number of oxidative reactions. The conversion of superoxide into hydrogen peroxide and decomposition of hydrogen-peroxide presents the first line of cellular defense to prevent deleterious biological oxidation by oxygen radical generated during cellular metabolism. Despite the presence of an efficient antioxidant system, oxidative stress still occurs in plant cells, either due to uncontrolled production or inefficient scavenging of ROS [30]. The reaction of antioxidant system depends on a few crucial factors such as duration to which the cell gets exposed to the oxidative stress and ecological context of oxidative stress as well as the ratio between antioxidants and also between ROS $\left(\mathrm{O}_{2} \bullet-, \mathrm{H}_{2} \mathrm{O}_{2}, \bullet \mathrm{OH}\right)$. In fact, the antioxidant defenses in living cells can respond to prooxidative conditions, when oxidative stress is not very strong, with a compensatory mechanism that increases the antioxidant activities [31]. If oxidative stress is persisting, or its level is very high, the protein damage became profound and a decreased SOD activity may occur. Our results that antioxidant enzymes were induced in organic production are in agreement with results of Palmer et al. [28] who also indicated that environment drivers may affect biochemical indicators and yields in organic systems more than in conventional systems.

\subsection{Total phenol content, DPPH and FRAP}

Total phenol content ranged from 698.10 (Eco-10 spelt, organic) to $877.20 \mathrm{mg} / 100 \mathrm{~g} \mathrm{dw}$ catechin eq. (Ebners-R spelt, organic). FRAP values ranged from 25.25 (Eco-10 spelt conventionally produced) to 39.35 FRAP units (Ebners-R spelt, organic). DPPH antiradical power ranged from 1.52 (Ebners-R spelt, organic) to 2.75 (Eco-10 spelt, organic). Results are given in Table 1.

No significant differences between organic and conventional spelt were observed considering total phenol content and FRAP values. Nevertheless, organic produced spelt showed significantly lower DPPH than conventional, for $38.05 \%$ (Eco-10) and $35.15 \%$ (Nirvana). A significant positive correlation was found between total phenol content and FRAP values $(\mathrm{r}=0.861 ; p<0.05)$. DPPH was also positively correlated, but insignificantly, with TPC and FRAP. Significant negative correlation was found between LP and DPPH $(\mathrm{r}=-0.869 ; p<0.05)$. Correlation matrix is presented in Table 2.

According to Grinder-Pedersen et al. [32], different food production methods may result in differences in the content of secondary metabolites such as polyphenolic compounds. Polyphenolic compounds are strong natural antioxidants and also part of the plant defence system with variety of functions [33]. The presence and content of different polyphenols are intraspecifically dependant and also affected by cultivation, harvesting conditions such as growing conditions, degree of ripeness and variety of the plants. Only a limited number of studies have investigated the effect of cultivation technique on the content of flavonoids, and the results are inconsistent [32]. Chemicals used in conventional production such as synthetic herbicides, pesticides, insecticides and fertilizers may both decrease and increase the production of polyphenolic compounds in plants [34, 35]. Organic food production is characterized by the absence or limited use of synthetic herbicides, pesticides, and insecticides and a lower use of fertilizers. Our results considering Eco-10 and Nirvana spelt genotypes pointed out no significant effect of the cultivation technique on total phenol content and FRAP values. These results are in accordance with previously reported studies of polyphenol content in three different strawberry cultivars in the organic

Table 2 Correlation matrix for antioxidant and scavenging activities of organic and conventional spelt and wheatgrass

\begin{tabular}{lcccccc}
\hline & GPx & SOD & LP & TPC & DPPH & FRAP \\
\hline SPC & -0.173 & -0.350 & -0.485 & 0.026 & 0.087 & 0.358 \\
GPx & & -0.085 & 0.345 & 0.258 & -0.570 & 0.033 \\
SOD & & & -0.377 & 0.641 & 0.469 & 0.673 \\
LP & & & -0.611 & $-0.869^{*}$ & -0.699 \\
TPC & & & & 0.464 & $0.861^{*}$ \\
DPPH & & & & & & 0.442 \\
\hline
\end{tabular}

The correlations marked with asterix were statistically significant at $p<0.05$ level.

$\mathrm{SPC}(\mathrm{mg} / \mathrm{ml})$ - soluble protein content; GPx (U/mg protein) - guaiacol peroxidase activity; SOD (U/mg protein) - superoxide dismutase activity; LP MDA (nmol/mg protein) - lipid peroxidation enzyme, TPC (catechin eq $(\mathrm{mg} / 100 \mathrm{~g} \mathrm{dw})$ ) - total phenolic content 
and conventional systems where no difference was seen [35]. Nevertheless, DPPH was lower in conventionally produced spelt genotypes what can be explained by the direct effect of certain chemicals used in production or their metabolites on this DPPH radical scavenging, or by the accumulation specific polyphenols with high scavenging potential towards DPPH radical. The highest value for all three antioxidant parameters were detected for organic Ebners-R spelt variety.

\subsection{Relative antioxidant capacity index (RACI) and phenolic antioxidant coefficients (PAC)}

In various methods for AOC activity determination, efficiency of AOs can vary due to the different chemical mechanisms lying behind the assays. In order to achieve a more reliable comparison between the samples analyzed, two additional parameters such as a relative antioxidant capacity index (RACI), calculated by assigning equal weight to all AOC assays applied (including TPC as a measure of total reducing activity), and phenolic antioxidant coefficients (PAC), calculated as a ratio between particular AOC capacity and total phenolic content, were introduced.

As seen in Fig. 1, the highest values of RACI were ascribed to spelt Ebners-R and wheat Europa 90 (0.501 and 0.447$)$. Low but still positive values of RACI were obtained for organically grown spelt Nirvana (0.119) and spelt Eco-10 (0.057). The negative values of RACI were calculated for spelt Nirvana (-0.695) and spelt Eco-10 (-0.430), which were conventionally raised.

The PAC calculation enables the comparison of the effectiveness of phenolics present in analysed samples and also provides specific insight into differences between applied AOC assays. Variations of both $\mathrm{PAC}_{\mathrm{SOD}}$ and $\mathrm{PAC}_{\mathrm{FRAP}}$ were remarkable, while variations in $\mathrm{PAC}_{\mathrm{LP}}$ and $\mathrm{PAC}_{\mathrm{GPx}}$ were much lower. The lowest values of $\mathrm{PAC}_{\mathrm{DPPH}}$ have been ascribed to samples with higher values of RACI, i.e. high AOC value. High PAC of organic and conventional spelt

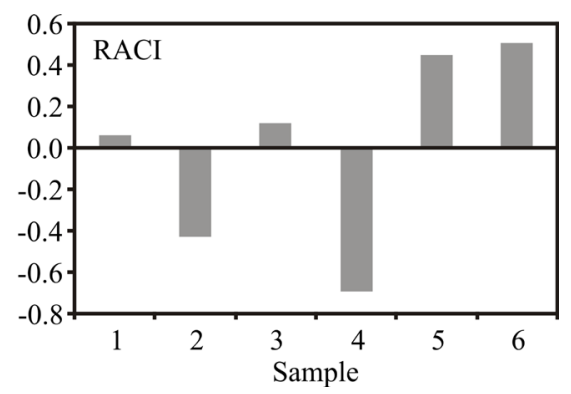

Fig. 1 Relative antioxidant capacity index (RACI) "Samples are numbered according to Table 1. and wheatgrass did not seem to be always associated with high AOC value (Fig. 2).

\subsection{PCA analysis}

The orientation of the vector describing the variable in factor space indicates an increasing trend of these variables, and the length of the vector is proportional to the square of the correlation values between the fitting value for the variable and the variable itself. The angles between corresponding variables indicate the degree of their correlations (small angles corresponding to high correlations).

The PCA of the presented AOC data explained that the first two components accounted for $74.32 \%$ of the total variance (50.54 and $23.78 \%$, respectively) in the seven variables (AOC assays, TPC and SPC). Considering the map of the PCA performed on the data, LP (which contributed $23.1 \%$ of total variance, based on correlations), exhibited a positive score according to the calculation of the first principal component, while SOD (13.8\%), TPC (19.0\%), FRAP (22.2\%) and DPPH (18.4\%) showed a negative influence for the first principal component (Fig. 3). The positive contribution to the second principal component was observed for SPC (21.1\% of total variance, based on correlations), while the negative contribution to the second principal component calculation was observed for GPx (34.7\%), SOD (13.4\%) and TPC (13.6\%). The points shown in the PCA graphics, which are geometrically close to each other indicate the similarity of patterns that represent these points. The first principal component is determined by the influence of LP, DPPH, FRAP, TPC and SOD, and it represents the differences in AOC of the samples. The most intensive AOC activity was observed for Ebners-R, while the lowest FRAP value was obtained for Eco-10. Nirvana and Europa samples were close to obtained AO activity. The second PC shows the differences in protein content. Conventionally grown samples were characterized by higher soluble protein content (Nirvana), while organically grown samples showed the higher GPx value.

The presented results represent a platform for the future research, which will be focused on the more detailed exploration of wheat and spelt grass phytochemical potential and corresponding biological activities.

\section{Conclusion}

Differences in antioxidant status of all three investigated Spelt genotypes (Eco-10, Nirvana and Ebners-Rotkorn) were observed between each other as well as in comparison with wheat. The highest superoxide-scavenging activity, 

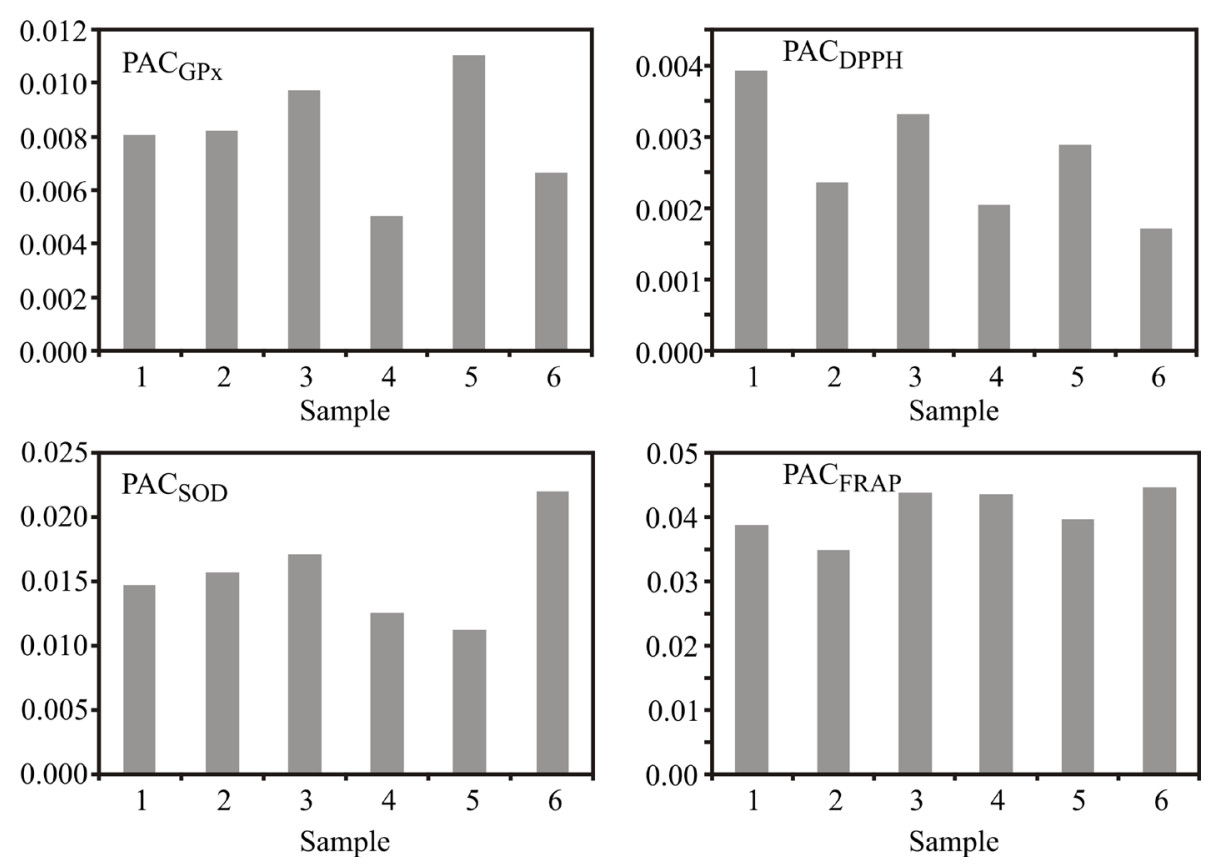

Fig. 2 Phenolic antioxidant coefficients (PAC) of organic and conventional spelt and wheatgrass

"Samples are numbered according to Table 1.

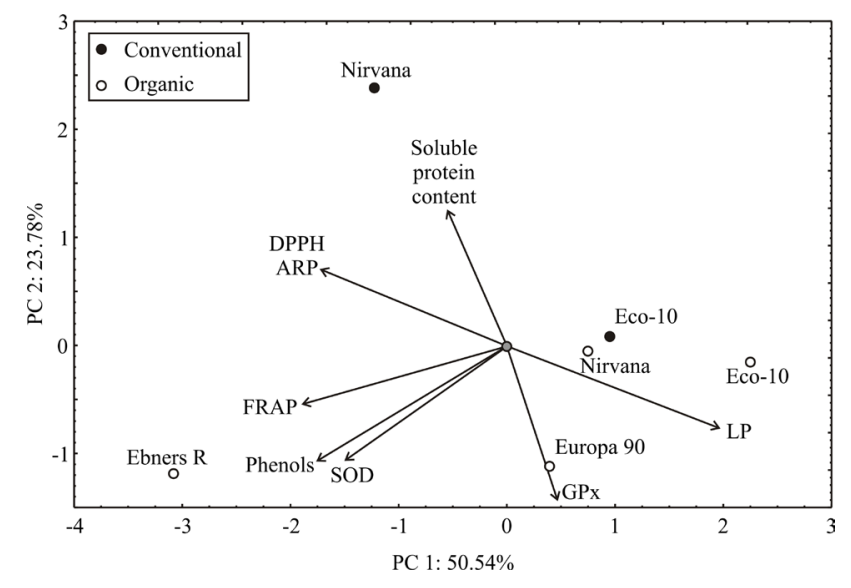

Fig. 3 PCA ordination of AOC variables based on component correlations

ferric reducing antioxidant power, total phenol content, DPPH antiradical power and the lowest lipid peroxidation intensity was observed in Ebners-Rotkorn genotype, even better than organically produced wheat. Comparative analysis of organically and conventionally produced spelt genotypes Eco-10 and Nirvana indicated that DPPHantiradical power was induced in both genotypes by conventional production. Regardless the lower DPPH, and slightly increased LP, organically produced spelt possess high antioxidant capacity that can resist towards oxidative stress by induction of antioxidant enyzmes. The presented results represent a platform for the future research, which will be focused on the more detailed exploration of wheat and spelt grass phytochemical potential and corresponding biological activities.

\section{Acknowledgement}

This research is part of Project no. III 46005 which is financially supported by the Ministry of Science, Education and Technology Development of the Republic of Serbia. The authors also would like to thank Provincial Secretariat for Higher Education and Scientific Research, Autonomous Province of Vojvodina, Republic of Serbia, for financial support (Grant No. 114-451-2079/2016-03).

$\begin{array}{ll}\text { Nomenclature } & \\ \text { AOC } & \text { antioxodant capacity } \\ \text { DPPH -2,2' } & \text { Diphenyl-1-Picrylhydrazyl } \\ \text { GPx } & \text { guaiacol peroxidase } \\ \text { FC } & \text { Folin Ciocalteu - phenol reagent } \\ \text { FRAP } & \text { ferric reducing antioxidant power } \\ \text { LCA } & \text { life cycle assessment } \\ \text { LP } & \text { lipid peroxidation } \\ \text { MDA } & \text { malondialdehyde } \\ \text { NBT } & \text { Nitro Blue Tetrazolium } \\ \text { PAC } & \text { phenolic antioxidant coefficients } \\ \text { PCA } & \text { Principal Component Analysis } \\ \text { SOD } & \text { superoxide dismutase } \\ \text { TBA } & \text { thiobarbituric acid } \\ \text { TPC } & \text { Total phenols content } \\ \text { TPTZ } & \text { 2,4,6-Tripyridyl-Triazine }\end{array}$




\section{References}

[1] Gawlik-Dziki, U., Świeca, M., Dziki, D. "Comparison of Phenolic Acids Profile and Antioxidant Potential of Six Varieties of Spelt (Triticum spelta L.)", Journal of Agricultural and Food Chemistry, 60(18), pp. 4603-4612, 2012.

https://doi.org/10.1021/jf3011239

[2] Zielinski, H., Michalska, A., Ceglinska, A. "Antioxidant properties of spelt bread", Polish Journal of Food and Nutrition Sciences, 58(2), pp. 217-222, 2008. [online] Available at: http://journal. pan.olsztyn.pl/ANTIOXIDANT-PROPERTIES-OF-SPELTBREAD-,98126,0,2.html [Accessed: 10 May 2018]

[3] Bodroža-Solarov, M., Vujić, Đ., Ačanski, M., Pezo, L., Filipčev, B., Mladenov, N. "Characterization of the liposoluble fraction of common wheat (Triticum aestivum) and spelt (T. aestivum ssp. spelta) flours using multivariate analysis", Journal of the Science of Food and Agriculture, 94(13), pp. 2613-2617, 2014.

https://doi.org/10.1002/jsfa.6655

[4] Fiemset, L. O., De Boever, L. J., Vanacker, J. M., De Campeneere, S., De Brabander, D. L. "Spelt as an ingredient in concentrates for rearing calves", Livestock Science, 150(1-3), pp. 349-356, 2012. https://doi.org/10.1016/j.livsci.2012.10.002

[5] Abdel Aal, E.-S., Rabalski, I. "Bioactive Compounds and their Antioxidant Capacity in Selected Primitive and Modern Wheat Species", The Open Agriculture Journal, 2, pp. 7-14, 2008. [online] Available at: https://benthamopen.com/contents/pdf/ TOASJ/TOASJ-2-7.pdf [Accessed: 10 May 2018]

[6] Luthria, D. L., Lu., Y., Maria John, K. M. "Bioactive phytochemicals in wheat: Extraction, analysis, processing, and functional properties", Journal of Functional Foods, 18, pp. 910-925, 2015. https://doi.org/10.1016/j.jff.2015.01.001

[7] Deng, G.-F., Xub, X.-R., Guoa, Y.-J., Xia, E.-Q., Lia, S., Wu, S., Chen, F., Ling, W.-H., Li, H.-B. "Determination of antioxidant property and their lipophilic and hydrophilic phenolic contents in cereal grains", Journal of Functional Foods, 4(4), pp. 906-914, 2012. https://doi.org/10.1016/j.jff.2012.06.008

[8] Yu, L., Zhou, K., Parry, J. W. "Inhibitory effects of wheat bran extracts on human LDL oxidation and free radicals", LWT-Food Science and Technology, 38(5), pp. 463-470, 2005. https://doi.org/10.1016/j.lwt.2004.07.005

[9] Hippocrates Health Institute "Wheatgrass Juice Benefits Nutrient profile, Weight Loss \& Fighting Disease", Hippocrates Health Institute, [online] Available at: http://hippocratesinst.org/living-food/benefits-of-wheatgrass [Accessed: 10 May 2018]

[10] Sprout People "Spelt grass", [online] Available at: http://sproutpeople.org/spelt-grass/ [Accessed: 10 May 2018]

[11] Durairaj, V., Hoda, M., Shakya, G., Pajaniradje, S., Babu, P., Rajagopalan, R. "Phytochemical screening and analysis of antioxidant properties of aqueous extract of wheatgrass", Asian Pacific Journal of Tropical Medicine, 7(Supplement 1), pp. S398-S404, 2014.

https://doi.org/10.1016/S1995-7645(14)60265-0
[12] Dudonné, S., Vitrac, X., Coutière, P., Woillez, M., Mérillon, J.-M. "Comparative Study of Antioxidant Properties and Total Phenolic Content of 30 Plant Extracts of Industrial Interest Using DPPH, ABTS, FRAP, SOD, and ORAC Assays", Journal of Agricultural and Food Chemistry, 57(5), pp. 1768-1774, 2009. https://doi.org/10.1021/jf803011r

[13] Kahl, J., Bodroza-Solarov, M., Busscher, N., Hajslova, J., Kneifel, W., Kokornaczyk, M. O., Van Ruth, S., Schulzova, V., Stolz, P. "Status quo and future research challenges on organic food quality determination with focus on laboratory methods", Journal of the Science of Food and Agriculture, 94(13), pp. 2595-2599, 2014. https://doi.org/10.1002/jsfa.6553

[14] Venkat, K. "Comparison of Twelve Organic and Conventional Farming Systems: A Life Cycle Greenhouse Gas Emissions Perspective", Journal of Sustainable Agriculture, 36(6), pp. 620649, 2012.

https://doi.org/10.1080/10440046.2012.672378

[15] Nemecek, T., Dubois, D., Huguenin-Elie, O., Gaillard, G. "Life cycle assessment of Swiss farming systems: I. Integrated and organic farming", Agricultural Systems, 104(3), pp. 217-232, 2011. https://doi.org/10.1016/j.agsy.2010.10.002

[16] Abdel-Aal, E.-S. M., Hucl, P. "Einkorn: A Functional Wheat for Developing High-Lutein Whole Grain Baked Products", Cereal Foods World, 59(1), pp. 5-10, 2014.

https://doi.org/10.1094/CFW-59-1-0005

[17] Jablonskytė-Raščè, D., Maikštenienė, S., Mankevičienė, A., "Evaluation of productivity and quality of common wheat (Triticum aestivum L.) and spelt (Triticum spelta L.) in relation to nutrition conditions", Zemdirbyste-Agriculture, 100(1), pp. 45-56, 2013.

https://doi.org/10.13080/z-a.2013.100.007

[18] Ie, P. S., Petros, D., Stinner, D. H., Phelan, P. L., Hamaker, B., Koelling K. W., Vodovotz Y. "Comparison of the Gelatinization Behavior of Organic and Conventional Spelt Starches Assessed by Thermal and Rheological Analyses", Journal of Agricultural and Food Chemistry, 60(36), pp 9229-9235, 2012.

https://doi.org/10.1021/jf301171j

[19] Hack, H., Gall, H., Klemke, T., Klose, R., Meier, U., Stauss, R., Witzenberger, A. "The BBCH-scale for phenological growth stages of potato (Solanum tuberosum L.)" In: Proceedings of the 12th Annual Congress of the European Association for Potato Research, Paris, France, 1993, pp. 153-154.

[20] Giannopolitis, C. N., Ries, S. K. "Superoxide dismutases I. Occurrence in higher plants", Plant Physiology, 59, pp. 309314, 1977. [online] Available at: https://www.ncbi.nlm.nih. gov/pmc/articles/PMC542387/pdf/plntphys00136-0196.pdf [Accessed: 10 May 2018]

[21] Kato, M., Shimizu, S. "Chlorophyll metabolism in higher plants. VII. Chlorophyll degradation in senescing tobacco leaves; phenolic dependent peroxidative degradation", Canadian Journal of Botany, 65(4), pp. 729-735, 1987. https://doi.org/10.1139/b87-097 
[22] Bradford, M. M. "A rapid and sensitive method for the quantitation of microgram quantities of protein utilizing the principle of protein-dye binding", Analytical Biochemistry, 72(1-2), pp. 248-254, 1976.

https://doi.org/10.1016/0003-2697(76)90527-3

[23] Singleton, V. L., Orthofer, R., Lamuela-Raventos, R. M. "Analysis of total phenols and other oxidation substrates and antioxidants by means of foline ciocalteau reagent", Methods in Enzymology, 299, pp. 152-178, 1999 . https://doi.org/10.1016/S0076-6879(99)99017-1

[24] Vinson, J. A., Proch, J., Bose, P. "Determination of quantity and quality of polyphenol antioxidants in foods and beverages", Methods in Enzymology, 335, pp. 103-114, 2001. https://doi.org/10.1016/S0076-6879(01)35235-7

[25] Brand-Williams, W., Cuvelier, M. E., Berset, C. "Use of a free radical method to evaluate antioxidant activity", LWT-Food Science and Technology, 28(1), pp. 25-30, 1995. https://doi.org/10.1016/S0023-6438(95)80008-5

[26] Benzie, I. F. F., Strain, J. J. "Ferric reducing antioxidant power assay: Direct measure of total antioxidant activity of biological fluids and modified version for simultaneous measurement of total antioxidant power and ascorbic acid concentration", Methods in Enzymology, 299, pp. 15-27, 1999. https://doi.org/10.1016/S0076-6879(99)99005-5

[27] Ng, T. B., Liu, F., Wang, Z. T. "Antioxidative activity of natural products from plants", Life Sciences, 66(8), pp. 709-723, 2000. https://doi.org/10.1016/s0024-3205(99)00642-6

[28] Palmer, M. W., Cooper, J., Tetard-Jones, C., Srednicka-Tober, D., Baranski, M., Eyre, M., Shotton, P. N., Volakakisa, N., Cakmak, I., Ozturk, L., Leifert, C., Wilcockson, S. J., Bilsborrow, P. E. "The influence of organic and conventional fertilisation and crop protection practices, preceding crop, harvest year and weather conditions on yield and quality of potato (Solanumtuberosum) in a long-term management trial", European Journal of Agronomy, 49, pp. 83-92, 2013.

https://doi.org/10.1016/j.eja.2013.03.004

[29] Popović, B. M., Štajner, D., Ždero, R., Orlović, S., Galić, Z. "Antioxidant characterization of oak extracts combining spectrophotometric assays and chemometrics", The Scientific World Journal, 2013, ID: 134656, 2013.

http://doi.org/10.1155/2013/134656
[30] Štajner, D., Milic, N., Canadanovic-Brunet, J., Kapor, A., Štajner, M., Popović, B. M. "Exploring Allium species as a source of potential medicinal agents", Phytotherapy Research, 20(7), pp. 581-584, 2006. http://doi.org/10.1002/ptr.1917

[31] Guerfel, M., Ouni, Y., Boujnah, D., Zarrouk, M. "Photosynthesis parameters and activities of enzymes of oxidative stress in two young 'Chemlali' and 'Chetoui' olive trees under water deficit", Photosynthetica, 47, pp. 340-346, 2009.

http://doi.org/10.1007/s11099-009-0054-z

[32] Grinder-Pedersen, L., Rasmussen, S. E., Bügel, S., Jørgensen, L. V., Dragsted, L. O., Gundersen, V., Sandström, B. "Effect of Diets Based on Foods from Conventional versus Organic Production on Intake and Excretion of Flavonoids and Markers of Antioxidative Defense in Humans", Journal of Agricultural and Food Chemistry, 51(19), pp. 5671-5676, 2003. http://doi.org/10.1021/jf030217n

[33] Strack, D. "Phenolic metabolism", In: Dey, P. M., Harborne, J. B., (eds.) Plant Biochemistry, 1st ed, Academic Press, San Diego, CA, USA, 1997, pp. 387-416.

[34] Capuano, E., Boerrigter-Eenling, R., van der Veer, G., van Ruth, S. M. "Analytical authentication of organic products: an overview of markers", Journal of the Science of Food and Agriculture, 93(1), pp. 12-28, 2012.

http://doi.org/10.1002/jsfa.5914

[35] Mditshwa, A., Magwaza, L. S., Tesfay, S. Z., Mbili, N. "Postharvest quality and composition of organically and conventionally produced fruits: A review", Scientia Horticulturae, 216, pp. 148-159, 2017.

https://doi.org/10.1016/j.scienta.2016.12.033

[36] Giampieri, F., Tulipani, S., Alvarez-Suarez, J. M., Quiles, J. L., Mezzetti, B., Battino, M. "The strawberry: Composition, nutritional quality, and impact on human health" Nutrition, 28(1), pp. 9-19, 2012.

http://doi.org/ 10.1016/j.nut.2011.08.009 